\title{
Effects of saponins on bile acids and plasma lipids in the rat
}

\author{
BY D. G. OAKENFULL, DOROTHY E. FENWICK \\ AND R. L. HOOD \\ CSIRO Division of Food Research, PO Box 52, North Ryde, NSW 2113
AND D. L. TOPPING, R. L. ILLMAN AND G. B. STORER
CSIRO Division of Human Nutrition, Kintore Avenue, Adelaide, South Australia 5000, Australia

(Received 16 October 1978 - Accepted 9 May 1979)

\begin{abstract}
I. The effects of feeding isolated saponins on plasma lipid concentrations and on concentrations of biliary and faecal bile acids and neutral sterols were studied in the rat.

2. The animals were given one of four diets, i.e. a standard low-cholesterol synthetic diet, the diet $+10 \mathrm{~g}$ saponins $/ \mathrm{kg}$, the diet + Io g cholesterol $/ \mathrm{kg}$, the diet $+10 \mathrm{~g}$ cholesterol $+\mathrm{Io} \mathrm{g}$ saponins $/ \mathrm{kg}$.

3. Saponins partially reversed the hypercholesterolaemia caused by the high-cholesterol diet and increased both the rate of bile acid secretion and the faecal excretion of bile acids and neutral sterols. The proportionate contribution of the primary bile acids (particularly chenodeoxycholic) to faecal excretion was also increased by saponins.

4. The results are discussed in relation to the hypothesis that saponins act by inducing the adsorption of bile acids by dietary fibre.
\end{abstract}

Epidemiological studies have clearly shown that elevated concentrations of plasma cholesterol are a major risk factor in the aetiology of coronary heart disease (Kannel et al. 1971). Burkitt \& Trowell (1975) have proposed that dietary fibre may be hypocholesterolaemic and thus reduce the risk of coronary heart disease. The mechanism that has been suggested is that fibre adsorbs bile acids in the intestine. The consequent loss of bile acids by faecal excretion is then offset by an increase in hepatic conversion of cholesterol into bile acids.

Although various plant fibre fractions have been shown to adsorb bile acids in vitro (Eastwood \& Hamilton, 1968; Balmer \& Zilversmit, 1974; Birkner \& Kern, 1974; Kritchevsky \& Story, 1974) it has recently been found that only fibre preparations containing saponins adsorb bile acids to a significant extent (Oakenfull \& Fenwick, I978). Also, there is abundant evidence that purified saponins (Morgan et al. 1972; Malinow, McLaughlin, Kohler et al, 1977) and saponin-rich foods such as lucerne (Medicago sativa) (Horlick et al. I 967) or soya-bean protein (Sirtori et al. 1977; Fumagalli et al. 1978) are hypocholesterolaemic whereas wheat bran, which is free of saponins, has no effect on plasma cholesterol concentrations in man (Truswell \& Kay, 1976).

We have therefore examined the effects of dietary saponins on bile acid metabolism and plasma cholesterol in rats on diets low and high in cholesterol. The results confirmed that saponins lower plasma cholesterol concentrations. Increases in faecal bile acids and neutral sterols were observed, supporting the hypothesis that saponins act by inducing the adsorption of bile salts to fibre in the intestine.

A preliminary account of some of this work has been presented (Topping, Hood et al. 1978). 


\section{MATERIALS AND METHODS}

\section{Saponins}

The saponins were a commercial material (Saponin, White; Ajax Chemicals Ltd, Sydney). The supplier was unable to provide information as to its botanical origin. Thin layer chromatography on Kieselgel 6oF 254 (Merck, Darmstadt, West Germany) and developing with chloroform-methanol-formic acid-water [ $15: 7: \mathrm{I}: \mathrm{I} \cdot 8, \mathrm{v} / \mathrm{v}$ (Kartnig et al. 1972) showed that the material consisted of three different saponins with four others present in minor amounts. It differed chromatographically from quillaja saponin and was probably derived from the European soapwort (Saponaria officinalis).

\section{Animals and treatment}

Adult male Wistar rats of 260-290 g body-weight were used. They were housed in groups of three or four per cage, in an animal room maintained at $20 \pm 2^{\circ}$ with a daily cycle of $12 \mathrm{~h}$ dark and $\mathrm{I} 2 \mathrm{~h}$ light. They were given water $a d \mathrm{lib}$. and consumed daily $20 \mathrm{~g}$ of the diets which were based on a standard synthetic diet containing $80 \mathrm{~g}$ wheat bran $/ \mathrm{kg}$ (Sen et al. 1977). The diets were presented in the form of a fine powder so that the animals were unable to select some components and reject others.

The experiment was a $2 \times 2$ factorial design. The four groups, each of five animals, were: control (given the standard diet), saponins (diet + Io g saponins $/ \mathrm{kg}$ ), cholesterol (diet $+\mathrm{Iog}$ cholesterol $/ \mathrm{kg}$ ) and saponins + cholesterol (diet + Io g saponins + Io g cholesterol $/ \mathrm{kg}$ ).

At the start of the experiment the animals were randomly distributed so that bodyweights in the four experimental groups were similar, averaging $263 \mathrm{~g}$. At the end of the 3-week period of dietary modification the rats were fasted for $16 \mathrm{~h}$ and then anaesthetized with Nembutal ( $60 \mathrm{mg} / \mathrm{kg}$ body-weight; Abbott Laboratories, Sydney, NSW). The bile duct was cannulated and bile was collected for $30 \mathrm{~min}$ in specially modified I $\mathrm{ml}$ pipettes (Topping, Hood et al. 1978). At the end of the collection period the animals were bled for the determination of plasma lipids and the liver was removed, blotted dry and weighed.

Faeces were collected overnight from each group and immediately frozen for storage. The collections for each group were pooled for $7 \mathrm{~d}$ periods and dried over phosphorus pentoxide in preparation for the determination of faecal bile acids and neutral sterols.

\section{Analytical techniques}

Plasma was prepared by centrifuging the blood at $3000 \mathrm{rev} . / \mathrm{min}$ for $15 \mathrm{~min}$ at $20^{\circ}$. It was then assayed for cholesterol and triacylglycerols using standard enzymic-colorimetric methods (Boehringer-Mannheim, Smithfield, NSW).

Samples $(5 \mathrm{~g})$ of liver were homogenized and extracted with chloroform-methanol-water (Bligh \& Dyer, 1959) and the final chloroform solution of lipid was dried under nitrogen. The lipid was then redissolved in propan-2-ol and assayed for cholesterol using the same method as for plasma.

Bile acids and cholesterol in bile samples were separated by gas-liquid chromatography after the material had been subjected to alkaline hydrolysis (Makino et al. 1974) and the bile acids converted to the methyl trifluoroacetates (Ross et al. 1977). Quantitative estimates were made by comparison with authentic standards using $5 \alpha$-androstan- $3 \beta$-ol I $7 \beta$-carboxylic acid as an internal standard. (All standards were bought from Steraloids Inc., Wilton, New Hampshire, USA.) Muricholic acids were not detected but in previous experiments (Topping, Illman et al. 1978) the same techniques detected muricholic acids in rats of a different strain. Lipid phosphorus in bile was determined by the method of Murison et al. (1976). 
Faecal samples (usually $0.5 \mathrm{~g}$ dried material) were homogenized and extracted by the method of Subbiah (1973). Bile acid and neutral sterol concentrations were measured by the same methods as were used for the samples of bile.

\section{Statistical methods}

The statistical significance of differences between the groups and of interactions between the treatments were estimated by the analysis of variance (Brownlee, 1949). A value of $P<0.05$ was taken as the criterion of statistical significance. All values are shown as mean values with their standard errors.

\section{RESULTS}

Body- and liver weights

After 3 weeks on the synthetic diets the rats in the control group had gained approximately $80 \mathrm{~g}$ (Table 1). Rats given the diet containing both saponins and cholesterol gained significantly less weight than those in the other groups. This was not due to reduced dietary intake since the entire daily ration (see p. 2 I0) was consumed throughout the experiment.

When the rats were killed the livers from those given the control diet averaged $10.6 \mathrm{~g}$ (Table I). In rats given saponins the livers were slightly lighter but in the cholesterol group the mean was $14^{\circ} 9 \mathrm{~g}$, a significant increase. Feeding both saponins and cholesterol significantly reversed this increase in liver weight due to the high cholesterol diet.

\section{Plasma and liver lipids}

Plasma cholesterol concentrations in the control and saponin-fed rats did not differ significantly, averaging 59 and $60 \mathrm{mg} / \mathrm{I} 00 \mathrm{ml}$, respectively (Table 2). Plasma cholesterol concentrations were significantly raised in the cholesterol group. Feeding saponins and cholesterol significantly reduced this hypercholesterolaemia; there was no independent action of saponins on plamsa cholesterol concentrations but their interactive effect with the cholesterol diet was highly significant.

Plasma triacylglycerol concentrations did not differ significantly between the control and saponin groups (Table 2). The cholesterol diet raised plasma triacylglycerol concentrations and, as in the instance of plasma cholesterol, saponins had a significant hypolipidaemic action.

The mean concentration of cholesterol in the livers of rats given the control diet was $2.7 \mathrm{~g} / \mathrm{kg}$ liver and this was raised to $19 \mathrm{~g} / \mathrm{kg}$ liver in the cholesterol group. In the saponin and saponin + cholesterol groups the concentrations were 2.5 and $9.2 \mathrm{~g} / \mathrm{kg}$ liver respectively (Table 2). (This effect of saponins in lowering the liver cholesterol in rats on the highcholesterol diet was highly significant statistically.)

\section{Bile flow and composition}

In rats given the control and the saponin diets the volumes of bile produced during the $30 \mathrm{~min}$ collection period were similar, averaging $1 \cdot 3 \mathrm{ml} / \mathrm{kg}$ body-weight (Table 3 ). Feeding cholesterol, alone or with saponins, increased the rate of bile secretion nearly twofold.

Dietary saponins and cholesterol increased the rate of secretion of cholesterol and phospholipids in the bile (Table 3). However, the rate of secretion of bile acids in the saponin group did not differ from that in the controls. Feeding cholesterol significantly raised bile acid secretion and there was a further, interactive, increase in the group given saponins + cholesterol.

Dietary modification also produced considerable changes in the relative proportions of the bile acids (Table 4 ). In the control animals the principal bile acids were cholic and 
Table I. Final body-weight and liver weight $(g)$ of rats given modified diets* for three weeks

(Mean values with their standard errors)

\begin{tabular}{|c|c|c|c|c|c|c|c|c|}
\hline & \multicolumn{8}{|c|}{ Dietary modification } \\
\hline & \multicolumn{2}{|c|}{$\begin{array}{l}\text { None } \\
\text { (control) }\end{array}$} & \multicolumn{2}{|c|}{ + Saponins } & \multicolumn{2}{|c|}{+ Cholesterol } & \multicolumn{2}{|c|}{$\begin{array}{l}\text { + Saponins } \\
+ \text { cholesterol }\end{array}$} \\
\hline & Mean & SE & Mean & $\mathbf{S E}$ & Mean & SE & Mean & SE \\
\hline Initial body-wt & 261 & 10 & $26 I$ & 4 & 259 & 8 & 271 & 8 \\
\hline Final body-wt & 341 & 9 & 333 & 5 & 330 & 2 & 312 & 12 \\
\hline Liver wt & $10 \cdot 6$ & 0.3 & $9 \cdot 8$ & 0.3 & 14.9 & 0.4 & II $\cdot 8$ & 0.5 \\
\hline
\end{tabular}

Table 2. Concentrations of cholesterol and triacylglycerols in the plasma and liver of rats given modified diets*

(Mean values with their standard errors)

\begin{tabular}{llllllll}
\multicolumn{8}{c}{ Dietary modification } \\
\end{tabular}

Table 3. The rate of production of bile and the rate of secretion of cholesterol, phospholipids and bile acids $(/ \mathrm{kg}$ body-weight per $30 \mathrm{~min})$ in rats given modified diets*

(Mean values with their standard errors)

\begin{tabular}{|c|c|c|c|c|c|c|c|c|}
\hline & \multicolumn{7}{|c|}{ (Mean values with their standard errors) } & \\
\hline & \multicolumn{2}{|c|}{$\begin{array}{c}\text { None } \\
\text { (control) }\end{array}$} & \multicolumn{2}{|c|}{+ Saponins } & \multicolumn{2}{|c|}{ + Cholesterol } & \multicolumn{2}{|c|}{$\begin{array}{c}\text { + Saponins } \\
+ \text { cholesterol }\end{array}$} \\
\hline & Mean & SE & Mean & SE & Mean & SE & Mean & SE \\
\hline Bile flow $(\mu l)$ & 1300 & 80 & 1270 & 60 & 2360 & 90 & 2320 & 160 \\
\hline Cholesterol secretion $(\mu \mathrm{g})$ & 160 & 3 & 176 & Io & 367 & 27 & 498 & 50 \\
\hline $\begin{array}{l}\text { Phospholipid secretion } \\
\text { ( } \mu \mathrm{g} \text { phosphorus) }\end{array}$ & 4980 & 960 & 6370 & 290 & 10070 & 860 & 14600 & 350 \\
\hline Bile acid secretion $(\mu \mathrm{g})$ & 2320 & 470 & 2020 & 220 & 6630 & 1170 & 9080 & 990 \\
\hline
\end{tabular}

hyodeoxycholic with lesser amounts of chenodeoxycholic, deoxycholic and lithocholic. Feeding saponins abolished the secretion of lithocholic acid and reduced the contribution of chenodeoxycholic but increased that of deoxycholic. The cholesterol diet raised the contributions of cholic, deoxycholic and lithocholic acids and lowered those of chenodeoxycholic and hyodeoxycholic. Although in the rat the muricholic acids are also generally important constituents of the bile, in the present experiments none could be detected. In a 
Table 4. The effects of dietary modification* on the relative amounts ( $\mathrm{mmol} / \mathrm{mol}$ ) of the biliary bile acids

(Mean values with their standard errors)

\begin{tabular}{|c|c|c|c|c|c|c|c|c|c|c|}
\hline \multirow{2}{*}{$\begin{array}{c}\text { Dietary } \\
\text { modification }\end{array}$} & \multicolumn{2}{|c|}{ Cholic } & \multicolumn{2}{|c|}{$\begin{array}{l}\text { Chenode- } \\
\text { oxycholic }\end{array}$} & \multicolumn{2}{|c|}{$\begin{array}{l}\text { Deoxy- } \\
\text { cholic }\end{array}$} & \multicolumn{2}{|c|}{$\begin{array}{l}\text { Hyodeoxy- } \\
\text { cholic }\end{array}$} & \multicolumn{2}{|c|}{$\begin{array}{l}\text { Litho- } \\
\text { cholic }\end{array}$} \\
\hline & Mean & SE & Mean & SE & Mean & $\mathrm{SE}$ & Mean & SE & Mean & SE \\
\hline \multirow{5}{*}{$\begin{array}{l}\text { None (control) } \\
+ \text { Saponins } \\
+ \text { Cholesterol } \\
+ \text { Saponins } \\
\text { + cholesterol }\end{array}$} & 604 & 30 & 85 & 7 & 69 & 7 & 200 & 23 & 37 & II \\
\hline & 631 & II & 55 & 5 & IIO & 16 & 205 & 19 & $\dagger$ & \\
\hline & 681 & 25 & 4 & 4 & 226 & 17 & 43 & I0 & 46 & 5 \\
\hline & 660 & 15 & 2 & 3 & 277 & 19 & 29 & 6 & 32 & 2 \\
\hline & & & & & & & & & & \\
\hline
\end{tabular}

Table 5. The effects of dietary modification* on weekly faecal excretion of bile acids and neutral sterols ( $\mathrm{mg} / \mathrm{g}$ dry matter)

(Values are for pooled samples)

Period on diet (weeks)

\begin{tabular}{|c|c|c|c|c|c|c|}
\hline \multirow[b]{2}{*}{$\begin{array}{c}\text { Dietary } \\
\text { modification }\end{array}$} & \multicolumn{2}{|c|}{ I } & \multicolumn{2}{|c|}{2} & \multicolumn{2}{|c|}{3} \\
\hline & $\begin{array}{l}\text { Bile } \\
\text { acids }\end{array}$ & $\begin{array}{l}\text { Neutral } \\
\text { sterols }\end{array}$ & $\begin{array}{l}\text { Bile } \\
\text { acids }\end{array}$ & $\begin{array}{l}\text { Neutral } \\
\text { sterols }\end{array}$ & $\begin{array}{l}\text { Bile } \\
\text { acids }\end{array}$ & $\begin{array}{c}\text { Neutral } \\
\text { sterols }\end{array}$ \\
\hline None & 146 & 134 & 71 & 137 & 45 & $\mathrm{II}_{3}$ \\
\hline+ Sap & 181 & 357 & 235 & 425 & 168 & 329 \\
\hline + Cholesterol & 334 & $8 \mathrm{II}$ & 424 & 683 & 310 & 491 \\
\hline $\begin{array}{l}+ \text { Saponins } \\
+ \text { cholesterol }\end{array}$ & 486 & 956 & 305 & 790 & 357 & 599 \\
\hline
\end{tabular}

For details, see p. 2 10.

Table 6. The effects of dietary modification* on the relative distribution of the faecal bile acids

(Values are for pooled samples)

Bile acid ( $\mathrm{mmol} / \mathrm{mol}$ total bile acids)

$\begin{array}{lcccccc}\begin{array}{c}\text { Dietary } \\ \text { Modification }\end{array} & \text { Cholic } & \begin{array}{c}\text { Chenode- } \\ \text { oxycholic }\end{array} & \begin{array}{c}\text { Deoxy- } \\ \text { cholic }\end{array} & \begin{array}{c}\text { Hyode- } \\ \text { oxycholic }\end{array} & \begin{array}{c}\text { Litho- } \\ \text { cholic }\end{array} & \begin{array}{c}\text { 7-keto- } \\ \text { lithocholic }\end{array} \\ \begin{array}{l}\text { None (control) } \\ \text { + Saponins }\end{array} & 99 & 48 & 259 & 259 & 181 & 154 \\ \text { + Cholesterol } & 145 & 465 & 99 & 142 & 53 & 95 \\ \text { + Saponins } & 113 & 8 \mathrm{a} & 481 & 151 & 124 & 43 \\ + \text { cholesterol } & 159 & 227 & 324 & 111 & 132 & 47 \\ & & * & & & \end{array}$

similar experiment, using the same analytical techniques, levels of the muricholic acids up to $150 \mathrm{mmol} / \mathrm{mol}$ of the total were detected (Topping, Illman et al. 1978) and the limit of detection was less than $50 \mathrm{mmol} / \mathrm{mol}$ of total bile acids. Presumably the absence of muricholic acids in the present experiments represents a peculiarity of the strain of rat.

\section{Faecal bile acids and neutral sterols}

There was no significant difference between the pooled weights of faeces collected from the four groups of animals during I week. During the period of the experiment the total weekly 

Table 7. A summary of the statistical significance of effects of dietary
saponins and cholesterol

\begin{tabular}{|c|c|c|c|}
\hline Measurement & Saponin & Cholesterol & $\begin{array}{l}\text { Saponin } v \text {. } \\
\text { cholesterol } \\
\text { interaction }\end{array}$ \\
\hline Body-wt & NS & NS & $*$ \\
\hline Liver wt & NS & $* * *$ & $* * *$ \\
\hline $\begin{array}{l}\text { Plasma } \\
\text { Cholesterol } \\
\text { Triacylglycerols }\end{array}$ & $\begin{array}{l}\text { NS } \\
\text { NS }\end{array}$ & $\begin{array}{l}* * * \\
* *\end{array}$ & $\begin{array}{l}* * * \\
*\end{array}$ \\
\hline $\begin{array}{l}\text { Liver } \\
\text { Cholesterol } \\
\text { Triacylglycerols }\end{array}$ & $\begin{array}{l}\text { NS } \\
*\end{array}$ & $\begin{array}{l}* * * \\
* * *\end{array}$ & $\begin{array}{l}* * \\
* *\end{array}$ \\
\hline $\begin{array}{l}\text { Bile } \\
\text { Flow rate }\end{array}$ & NS & $* * *$ & NS \\
\hline $\begin{array}{l}\text { Cholesterol production } \\
\text { Phospholipid production }\end{array}$ & *** & $\begin{array}{l}* * * \\
* * *\end{array}$ & * \\
\hline $\begin{array}{l}\text { Biliary } \\
\text { Bile acid secretion }\end{array}$ & NS & $* * *$ & * \\
\hline $\begin{array}{l}\text { Bile acids } \\
\text { Chenodeoxycholic } \\
\text { Hyodeoxycholic } \\
\text { Lithocholic } \\
\text { Cholic } \\
\text { Deoxycholic }\end{array}$ & $\begin{array}{l}* * * \\
\text { NS } \\
* * * \\
\text { NS } \\
* * *\end{array}$ & $\begin{array}{l}* * * \\
* * * \\
* * \\
* * \\
* * *\end{array}$ & $\begin{array}{l}\text { * } \\
\text { NS } \\
\text { NS } \\
\text { NS } \\
\text { NS }\end{array}$ \\
\hline
\end{tabular}

faecal excretion of bile acids and neutral sterols fell in all groups. For each collection period, excretion of bile acids and neutral sterols was higher in the saponins group than in the controls and feeding cholesterol further raised the faecal excretion of bile acids and neutral sterols (Table 5). In the saponins + cholesterol group the faecal excretion of bile acids was higher than in the cholesterol group for 2 weeks of the 3 week period (see Table 5), while neutral sterol excretion was increased throughout the experiment.

The relative abundances of the bile acids in the final collection of faeces from each group are given in Table 6. In the control group the amounts of cholic and chenodeoxycholic acids were small and the secondary bile acids predominated. (The primary bile acids (cholic and chenodeoxycholic) are those synthesized in the liver. The secondary bile acids (deoxycholic, hyodeoxycholic, lithocholic) are derived from the primary bile acids by the action of bacteria in the intestine.) Feeding saponins increased the relative amount of chenodeoxycholic considerably and, to a lesser extent, that of cholic. There was a corresponding fall in the relative amounts of secondary bile acids, particularly those derived from chenodeoxycholic (i.e. lithocholic, hyodeoxycholic and 7-keto lithocholic). Feeding cholesterol increased the relative amounts of both cholic and chenodeoxycholic acid but the largest increase was in that of deoxycholic. However, in the group given the diet containing both saponins and cholesterol there was again a shift towards the primary acids.

\section{Statistical significance}

A summary of the statistical significance of the observed effects of dietary saponins and cholesterol is given in Table 7 . 


\section{DISCUSSION}

In rats offered a standard laboratory rat diet the principal bile acids produced by hepatic catabolism of cholesterol are cholic and chenodeoxycholic (Mitropoulos \& Myant, I 969). After conjugation with either glycine or taurine the bile acids are secreted in the bile. During their passage through the gut they are deconjugated and a certain proportion is dehydroxylated by the gut microflora; chenodeoxycholic is $7 \alpha$-dehydroxylated to lithocholic (Norman \& Sjöval, I960) and cholic is similarly converted into deoxycholic (Gustafsson et al. 1957). There is an efficient $(95-97 \%$ ) reabsorption of bile acids from the ileum from where they are returned to the liver in the portal blood stream (Heaton, 1972). In the rat there may be hepatic rehydroxylation of deoxycholic to cholic acid (Bergström \& Gloor, 1955) and a conversion of lithocholic into hyodeoxycholic acid by enzymes in both the liver and the gut microflora (Einarsson, 1966).

The enterohepatic circulation of bile acids ensures that only a small proportion of the total body pool is lost via the faeces. However, when the reabsorption of bile acids from the gut is blocked, for example by adsorption to the anion exchange resin cholestyramine, there is an increase in faecal excretion of bile acids (Huff et al. 1963; Beher et al. 1966). This depletion of the bile acid pool leads to an increased hepatic conversion of cholesterol into bile acids. In rats (Huff et al. 1963) there is little change in the plasma cholesterol concentration under these circumstances (probably due to a compensatory increase in synthesis) but in man (Thompson, 197I ; Farah et al. 1977) and dogs (Tennent et al. 1960) cholestyramine is hypocholesterolaemic. Burkitt \& Trowell (1975) have proposed that plant fibre may similarly adsorb bile acids and so lower the concentrations of plasma cholesterol.

In the experiments described here, dietary saponins lowered plasma and liver cholesterol concentrations in rats on the high-cholesterol diet and lowered liver cholesterol concentrations when the diet was low in cholesterol. Dietary saponins increased the excretion of bile acids and neutral sterols in the faeces and they induced a further increase in the rate of bile acid secretion when this was stimulated by a high-cholesterol diet.

Very similar results have been reported by Fumagalli et al. (1978) for experiments in which rabbits were given a diet containing soya-bean meal that had been extracted with hexane. Whole soya-beans contain approximately $5 \mathrm{~g}$ saponins $/ \mathrm{kg}$ and these are not removed by this extraction procedure (Smith \& Circle, 1972). When rabbits were given a diet containing soya-bean meal their plasma cholesterol concentrations were lower and they excreted up to $43 \%$ more neutral sterols and bile acids in their faeces than when they were given an equivalent diet in which the protein was casein.

All these dietary effects are consistent with an increased adsorption of bile acids to fibre induced by saponins, as observed in vitro by Oakenfull \& Fenwick (I978). In this respect saponins mimic the action of cholestyramine which, in addition to increasing the faecal excretion of bile acids, also increases that of neutral sterols (and other lipids) by inhibiting lipid absorption as a consequence of its ability to adsorb bile acids.

The effect of dietary saponins on the relative proportions of the faecal bile acids (Table 6) indicates a marked extent of specificity in the adsorption of bile acids induced by saponins. In the rats given the saponin diet the greatest increase in faecal bile acids was in chenodeoxycholic whereas the contribution of chenodeoxycholic to the biliary bile acids was depressed. Similarly in rats given the diet containing both saponins and cholesterol, chenodeoxycholic acid and its metabolites were major contributors to faecal bile acid excretion but were only a minor component of the bile. This specificity in adsorption is also observed with cholestyramine which adsorbs dihydroxy bile acids (such as chenodeoxycholic) in preference to cholic which is a trihydroxy bile acid (Hagerman et al. 1973). It also appears that dietary saponins inhibit the metabolism of bile acids by the gut microflora since in the presence of 
saponins the proportion of primary bile acids (particularly chenodeoxycholic) in the faeces increased while that of the secondary acids fell.

It may be concluded that the hypocholesterolaemic effects of dietary saponins are achieved by increased faecal excretion of bile acids and neutral sterols. Diets containing either isolated saponins or foods rich in saponins (such as soya beans) are known to be hypocholesterolaemic and may therefore prove to be of benefit in man; provided, as Malinow, McLaughlin, Papworth et al. (1977) have pointed out, that no toxic side effects occur.

\section{REFERENCES}

Balmer, J. \& Zilversmit, D. B. (1974). J. Nutr. r04, I3I9.

Beher, W. T., Beher, M. E. \& Rao, B. (1966). Proc. Soc. exp. Biol. Med. 122, 881.

Bergström, S. \& Gloor, U. (I955). Acta chem. scand. 9, I 545.

Birkner, J. H. \& Kern, F. (1974). Gastroenterology 67, 237.

Bligh, E. G. \& Dyer, W. J. (1959). Can. J. Biochem. Physiol. 37, 91 I.

Brownlee, K. A. (1949). Industrial Experimentation, 4th ed. London: H.M. Stationery Office.

Burkitt, D. P. \& Trowell, H. C. (1975). Refined Carbohydrate Foods and Disease. London: Academic Press.

Eastwood, M. A. \& Hamilton, D. (1968). Biochem. biophys. Acta 152, 165.

Einarsson, K. (I966). J. biol. Chem. 24I, 534.

Farah, J. R., Kwiterovich, P. O. \& Neil, C. A. (1977). Lancet i. 59.

Fumagalli, R., Paoletti, R. \& Howard, A. N. (1978). Life Sci. 22, 947.

Gustaffson, B. E., Bergström, S., Lindstedt, S. \& Norman, A. (I957). Proc. Soc. exp. Biol. Med. 94, 467.

Hagerman, L. M., Julow, D. A. \& Schneider, D. L. (1973). Proc. Soc. exp. Biol. Med. I43, 89.

Heaton, K. W. (1972), Bile Salts in Health and Disease. Edinburgh: Churchill-Livingstone.

Horlick, L., Cookson, F. B. \& Federoff, S. (I967). Circulation 35-6, 1 I.

Huff, J. W., Gilfillan, J. L. \& Hunt, V. M. (1963). Proc. Soc. exp. Biol. Med. 114, 352.

Kannel, W. B., Castelli, W. P., Gorodon, T. \& McNamara, P. M. (1971). Ann. intern. Med. 74, I.

Kartnig, Von Th., Ri, C. Y. \& Wegschaider, O. (1972). Planta Med. 22, 127.

Kritchevsky, D. \& Story, J. A. (1974). J. Nutr. 104, 458.

Makino, I., Shinozaki, K., Nakagawa, S. \& Mashimo, K. (1974). J. Lipid Res, r5, 132.

Malinow, M. R., McLaughlin, P., Kohler, G. O. \& Livingston, A. L. (1977). Steroids 29, 105.

Malinow, M. R., McLaughlin, P., Papworth, L., Stafford, C., Kohler, G. O., Livingston, A. L. \& Cheeke, P. R. (1977). Am. J. clin. Nutr. 30, 206I.

Mitropoulos, K. A. \& Myant, N. B. (1969). In Bile Salt Metabolism, p. II5 [L. Schiff, J. Carey and J: Dietschy, editors]. Springfield: Charles C. Thomas.

Morgan, B., Heald, M., Brooks, S. G., Tee, J. L. \& Green, J. (1972). Poult. Sci. 51, 677.

Murison, J., Festi, D., Ross, P. E. \& Bouchier, I. A. D. (1976). Clin. Chem. Acta. 68, 159.

Norman, A. \& Sjöval, J. (1960). Acta chem. scand. 14, 1815.

Oakenfull, D. G. \& Fenwick, D. E. (1978). Br. J. Nutr. 40, 299.

Ross, P. E., Pennington, C. R. \& Bouchier, I. A. D. (I977). Analyt. Biochem. 80, 458.

Sen, D. P., Bhandary, C. S., Murti, I. A. S., Rao, S. N., Bai. B. M. \& Pai, M. P. (1977).J. Am. Oil Chem. Soc. 54, 297.

Sirtori, C. R., Agradi, E., Conti, F., Mantero, O. \& Gatti, E. (1977). Lancet. i, 275.

Smith, A. K. \& Circle, S. J. (1972). Soybeans: Chemistry and Technology. Westport, Connecticut: Avi Publishing Co. Inc.

Subbiah, M. T. R. (1973). J. Lipid Res. 14, 692.

Tennent, D. M., Siegel, H., Zannetti, M. E., Kuron, G. W., Ott, W. H. \& Wolf, F. J. (1960). J. Lipid Res. r, 469 .

Thompson, W. G. (197I). Can. med. Ass. J. ro4, 305.

Topping, D. L., Hood, R. L., Illman, R. J., Storer, G. B. \& Oakenfull, D. G. (1978). Proc. Nutr. Soc. Aust. 3,68 .

Topping, D. L., Illman, R. J., Dreosti, I., Trimble, R. P. \& Record, I. R. (1978). Nutr. Rep. Int. (In the Press.)

Truswell, A. S. \& Kay, R. M. (1976). Lancet. i, 367. 